\title{
Analysis of sedimentary processes on the Las Canteras beach (Las Palmas, Spain) for its planning and management
}

\author{
J. Martínez Martínez, R. Alvarez Espejo, I. Alonso Bilbao and M.D. del \\ Rosario Cabrera \\ Facultad de Ciencias del Mar, Uniw de Las Palmas de Gran Canaria, Apartado de Correos \\ 550. Guia de G.C., Las Palmas de Gran Canaria 35017 (Spain)
}

(Accepted for publication February 1, 1990)

ABSTRACT

Martinez, Martincz, J., Alvarez Espejo, R., Alonso Bilbao, 1. and del Rosario Cabrera, M.D., 1990. Analysis of sedimentary processes on the Las Canteras beach (Las Palmas, Spa:n) for its planning and management. Eng. Geol., 29: 377-386.

The sedimentary dynamics of a sandy beach located on the North coast of the Island of Gran Canaria has been studied in relation to physical processes.

The morphodynamic behaviour of the beach has been established and interpretcd. Special emphasis has been placed on the characterization of crosive and accretionary processes by mcans of sediment transport calculations. Two sedimentary indices have been used to define these processes qualitatively and qua ntitatively. These indices are of imporlance for management.

\section{DESCRIPTION OF THE STUDIED AREA}

Located on the northeastern coast of Gran Canaria, the beach is shielded from the prevailing northeastern winds and swells (Fig.1). The total length of the beach is about $3000 \mathrm{~m}$, and is bounded to the north by a headland and southward by a groyne. This prevents lateral exchange of sediments with adjacent beaches (Fig.2). In certain areas, the width of the foreshore reaches $100 \mathrm{~m}$ while the backshore is about $50 \mathrm{~m}$. This is due to the range of tides, more than two and a half metres.

The submerged beach is partially cut-off by a rocky bar parallel to the shore and aboul $200 \mathrm{~m}$ from the beach face (Fig.2), which emerges during low tide periods. The presence of this partially destroyed bar is very important, since it establishes relatively protected and exposed areas along the beach. This is the main reason for which the beach has been divided into the following five stretches (Fig.2):

Las Canteras South (lines 1-3). This is the most exposed area.

Hemitombolo (lines 3-5) This stretch is sheltered by the southernpart of the bar, in which a hemitombolc has been developed. 

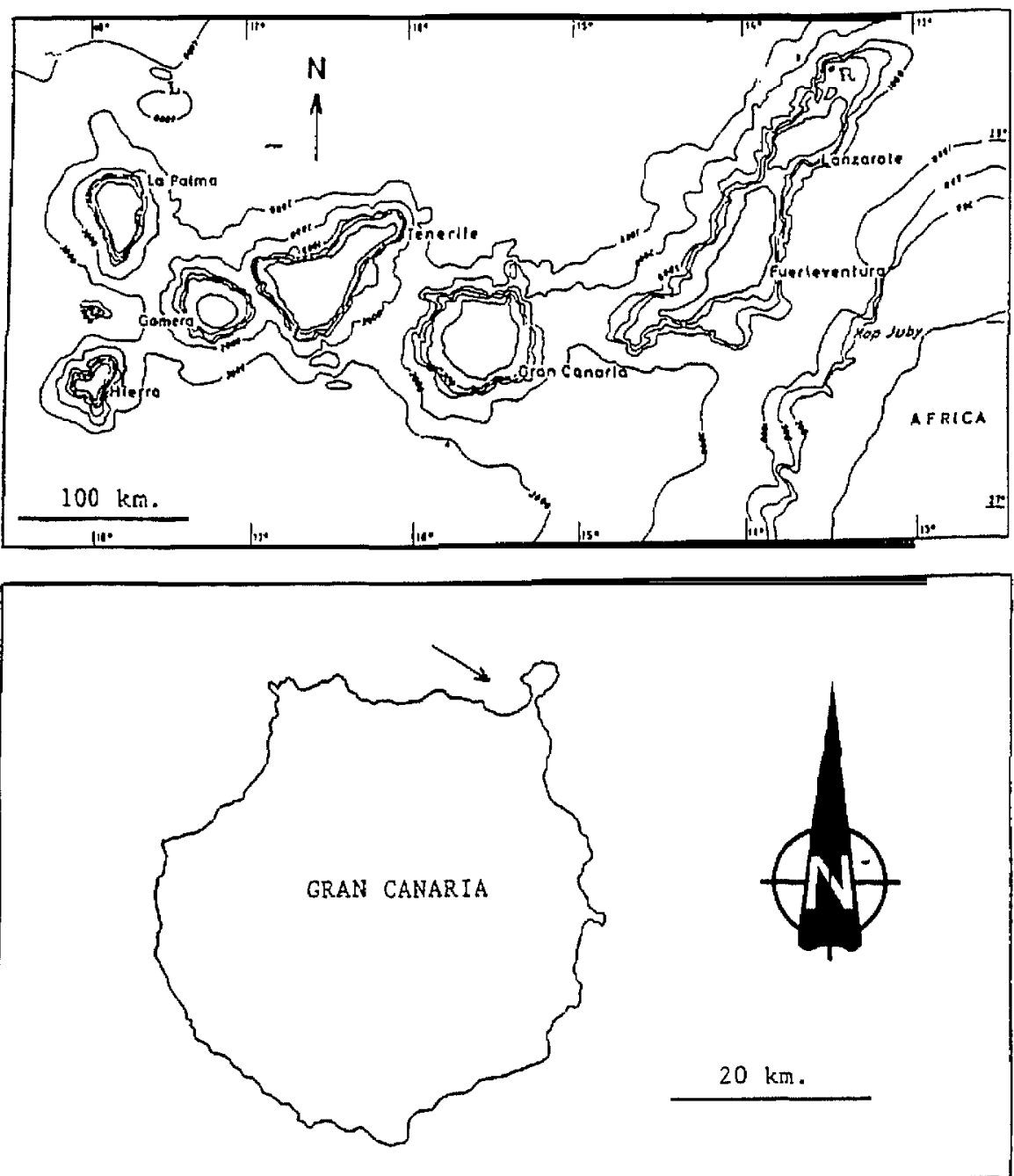

Fig.1. Location of the beach studied

Central Opening (lines 5-6). This is the zone situated opposite to the opening between the two main parts of the bar.

Short Beach (lines 8-10). This sector is quite short, but it has been considered separately, since it is.morphologically established as a pocket beach.

Las Canteras North (lines 10-16). This is the most protected area, not only because of the presence of the largest part of the bar, but alsc because of being the most sheltered place from the prevailing northeastern winds.

Diagrams of currents along the beach for the prevailing winds have been obtained 


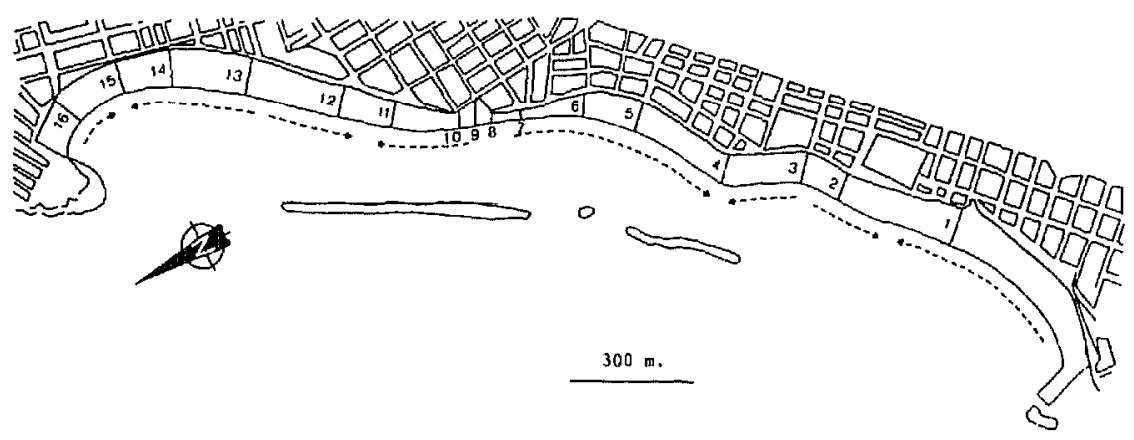

Fig.2. Sketch of Las Canteras beach. Numbers $1-16$ indicate the location of the profiles taken. Arrows represent the current pattern (see text).

by Martinez et al. (1988). The currents plotted on Fig.2 correspond to northeast wind conditions.

\section{METHODOLOGY}

The collected data include topographic surveys and sediment samples. Swell data from seagoing ships were also obtained. Sand samples were collected once a month during an annual cycle on certain fixed points along the beach on the intertidal zone. Samples were analyzed in the laboratory mainly for grain size and organic carbonate content.

Profiles were obtained from 16 sections using a leveling method on fixed transect lines along the beach (Fig.2). Surveys were conducted monthly during the lowest tidal periods, across the backshore and the foreshore, from July 1987 to July 1988. Making use of the data from the sections thus obtained, the volume of sand between them was calculated; for that purpose, a base elevation level $(10 \mathrm{~m}$ under a fixed point), and an intertidal strip $21 \mathrm{~m}$ wide were established.

Once the different monthly volumes of sand are calculated in cubic metres, it is possible to establish the sediment increases for each sector on the beach in relation to the lowest volume. The spatial and temporal evolution of these sedimentary variations can be qualitatively and quantitatively studied by means of two sedimentary indices: sediment variability and support capacity.

The sediment variability index is defined as the average change of height from the highest accretion to the greatest erosion, and vice versa, which takes place on the surface of the beach during a sedimentary cycle. It is the ratio between the net increase or decrease of sand in cubic metres and the delimited surface:

$\mathrm{SVI}=\Delta V / S$

where $\Delta V=$ variation in sediment volume (positive or negative), and $S=$ surface considered.

The sediment support capactiy index, enables the comparison between the actual 


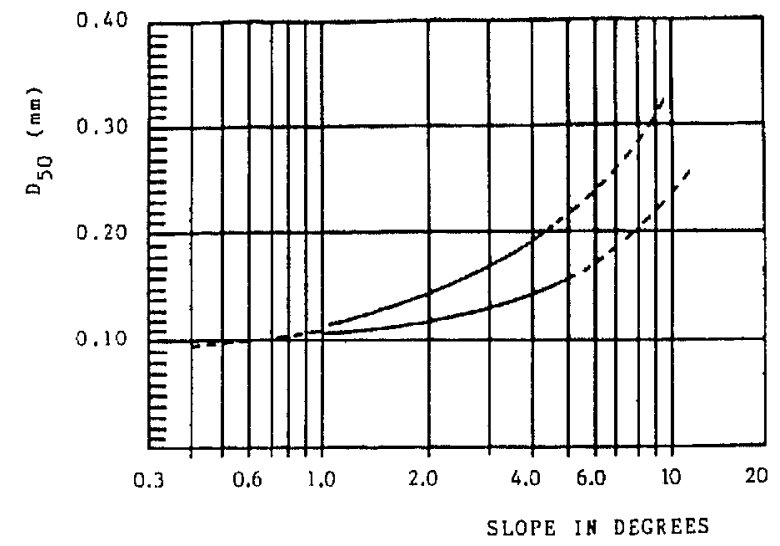

Fig.3. Relationship between beach-face angle and grain size for Canarian beaches.

surface of the beach face and a theoretical one. This ratio is obtained by means of the difference between the actual and the potential volume of sand, on a certain surface:

$\mathrm{SSCI}=\left(V_{\mathrm{r}}-V_{\mathrm{p}}\right) / S$

where $V_{\mathrm{r}}=$ actual volume, $V_{\mathrm{p}}=$ potential volume, $V_{\mathrm{p}}=L A[H-(A / 2) \operatorname{tg} \beta], L=$ length of the beach sector, $A=$ width of the intertidal strip ( $21 \mathrm{~m}$ in this case), $H=$ height difference between the upper tidal limit and the reference level, $\beta=$ slope of the intertidal strip, and $S=$ surface considered.

The potential volume is obtained once the theoretical slope is calculated. This may be done using expressions like those from Sunamura (1984). In the present work, an empirical curve relating grain size and slope of the beach face has been used (Fig.3). This curve is quite similar to those from Komar (1976) and Bascom (1951), but in this case it was obtained using data from Canarian beaches.

\section{RESULTS}

As may be seen from Table 1 , the medium grain size of sand for the entire beach is 0.23 millimeters. On the southern end of Las Canteras the grain size is finest, whereas the coarsest size appears on the short beach.

The content of organic carbonates, as shown in Table II, is about $38 \%$ of the total weight. Along the foreshore, the highest concentrations of carbonates are found in the coarsest fraction in Las Canteras North, and if the medium fraction at the southern end of the beach.

The above results allow, according to Martinez'1987), he establishment of two sedimentary sub-environments in the beach: Las Canteras South, with finer sands and a trend towards an open sedmentary system behaviour; and Las Canteras North, with coarser sediments and a trend towards a closed sedmentary system.

Table III presents monthly slope changes in different profilet-along the beach. Each 
TABLE I

Annual average of grain-size characteristics of sediment along the foreshore of the beach under study

\begin{tabular}{|c|c|c|c|c|c|c|c|c|}
\hline \multirow[b]{2}{*}{ Profile: } & \multicolumn{2}{|c|}{$\begin{array}{l}\text { Las Canteras } \\
\text { South }\end{array}$} & \multirow{2}{*}{$\begin{array}{l}\text { Hemitombolo } \\
4\end{array}$} & \multirow{2}{*}{$\begin{array}{l}\text { Central } \\
\text { opening } \\
6\end{array}$} & \multirow{2}{*}{$\begin{array}{l}\text { Short } \\
\text { beach } \\
9\end{array}$} & \multicolumn{2}{|c|}{$\begin{array}{l}\text { Las Canteras } \\
\text { North }\end{array}$} & \multirow[t]{2}{*}{$\begin{array}{l}\text { Mean } \\
\text { values }\end{array}$} \\
\hline & 1 & 2 & & & & 12 & 15 & \\
\hline \multicolumn{9}{|l|}{$\begin{array}{l}\text { Mean annual } \\
\text { values }\end{array}$} \\
\hline$Q_{1}(\mathrm{~mm})$ & 0.218 & 0.249 & 0.369 & 0.353 & 0.752 & 0.305 & 0.304 & 0.328 \\
\hline$Q_{2}(\mathrm{~mm})$ & 0.177 & 0.183 & 0.231 & 0.234 & 0.465 & 0.227 & 0.228 & 0.230 \\
\hline$Q_{3}(\mathrm{~mm})$ & 0.155 & 0.158 & 0.179 & 0.186 & 0.293 & 0.189 & 0.191 & 0.185 \\
\hline $\begin{array}{l}\text { Grain-size } \\
\text { classification* }\end{array}$ & A & A & B & $\mathrm{B}$ & $C$ & B & B & $B$ \\
\hline
\end{tabular}

${ }^{*} A=$ fine sand $B=$ medium-size sand with fine sand; $C=$ coarse sand with medium-size sand.

TABLE II

Mean annual carbonate contents in percentage of total weight for intertidal samples

\begin{tabular}{lll}
\hline Size $(\mathrm{mm})$ & Las Canteras North & Las Canteras South \\
\hline $\begin{array}{l}\text { Coarse size } \\
\phi>0.25\end{array}$ & 47.47 & $27.1 \mathrm{~L}$ \\
$\begin{array}{l}\text { Medium size } \\
0.25>\phi>0.15\end{array}$ & 44.57 & 39.38 \\
$\begin{array}{l}\text { Fine size } \\
\phi<0.15\end{array}$ & 25.08 & 10.34 \\
\hline
\end{tabular}

TABLF. III

Mcan slope of the foreshore strip on certain profile lines along the beach (values in \%)

\begin{tabular}{llllllr}
\hline $\begin{array}{l}\text { Date } \\
\text { of } \\
\text { survey }\end{array}$ & $\begin{array}{l}\text { Las Canteras } \\
\text { South }\end{array}$ & Hemitombolo & $\begin{array}{l}\text { Central } \\
\text { opening }\end{array}$ & & $\begin{array}{l}\text { Short } \\
\text { Beach }\end{array}$ & Las Canteras North \\
\hline July 87 & 1 & 4 & 6 & 9 & 13 & 15 \\
Aug. 87 & 4.70 & 4.83 & 6.12 & 7.76 & 7.95 & 9.58 \\
Sept. 87 & 4.03 & 4.36 & 6.63 & 7.21 & 9.33 & 10.17 \\
Oct. 87 & 2.86 & 3.84 & 6.65 & 6.69 & 7.92 & 8.24 \\
Nov. 87 & 3.76 & 3.27 & 6.31 & 6.47 & 7.28 & 7.76 \\
Dec. 87 & 3.40 & 3.84 & 4.98 & 6.33 & 8.54 & 8.71 \\
Jan. 88 & 3.90 & 3.30 & 4.80 & 6.14 & 6.42 & 6.15 \\
Feb. 88 & $3 . .15$ & 3.64 & 5.19 & 6.80 & 5.52 & 7.18 \\
March 88 & 4.0 & 2.71 & 5.02 & 7.00 & 6.35 & 6.59 \\
April 88 & 2.46 & 4.25 & 5.51 & 6.44 & 6.81 & 8.03 \\
May 88 & 2.82 & 4.20 & 5.29 & 6.53 & 7.36 & 9.09 \\
June 88 & 3.17 & 4.57 & 5.24 & 6.76 & 8.73 & 10.83 \\
July 88 & 2.5 .5 & 4.21 & 5.92 & 6.33 & 8.33 & 12.44 \\
Annual average & 3.45 & 5.72 & 5.82 & 6.49 & 7.95 & 9.86 \\
\hline
\end{tabular}


sector is represented by one line, with the exception of the northernmost one, where two profiles have been included. It can be seen that the slopes increase from line 1 , with $3.43 \%$, to line 16 , with $8.81 \%$. That is, the lesser slope lies on the most exposed stretch.

Comparing these data with those of Wright and Short (1983), the beach under study can be divided into two morphodynamic sub-environments:

(1) The southern end of Las Canteras can be identified as a nearly dissipative beach with a main annual slope of about $3.4 \%$ across the intertidal strip. In Fig. 4 the great variation of the profiles at line 1 , where the beach face reaches $100 \mathrm{~m}$, can be observed.

(2) The northern side of the beach, which can be compared to a reflective beach. In this case the average annual slope is in the range of $8.5 \%$, though sometimes the foreshore slope reaches $12 \%$. In Fig. 4 several profiles are plotted at line 15 . It is worthy to note that there is a very small difference between these profiles.

It must be noted that the dissipative sector coincides with the open sedimentary system and vice versa.

Figure 5 shows the monthly variation in sediment volume for the entire beach. This
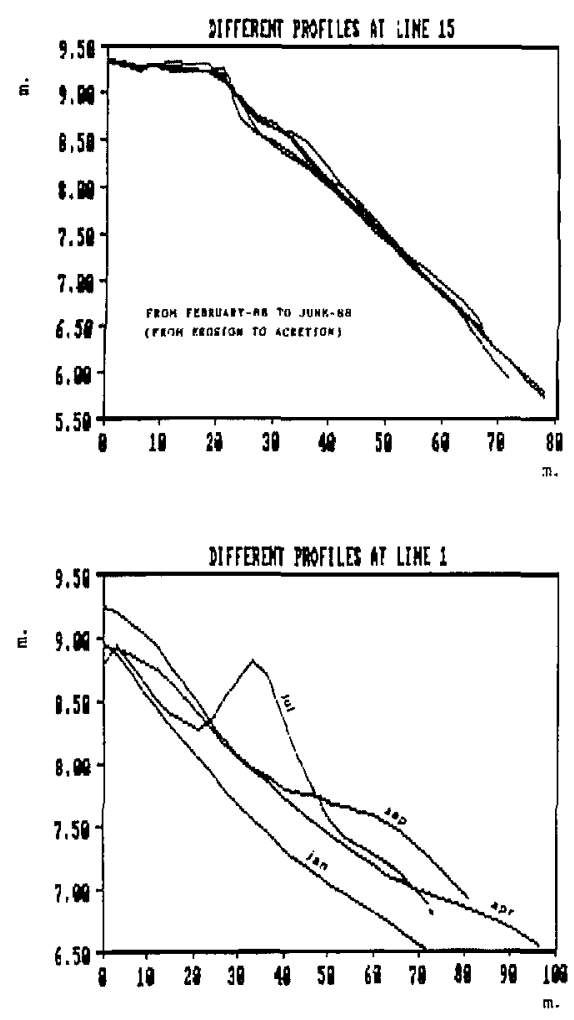

Fig.4. Monthly variations of two significant profiles in Las Canteras. 

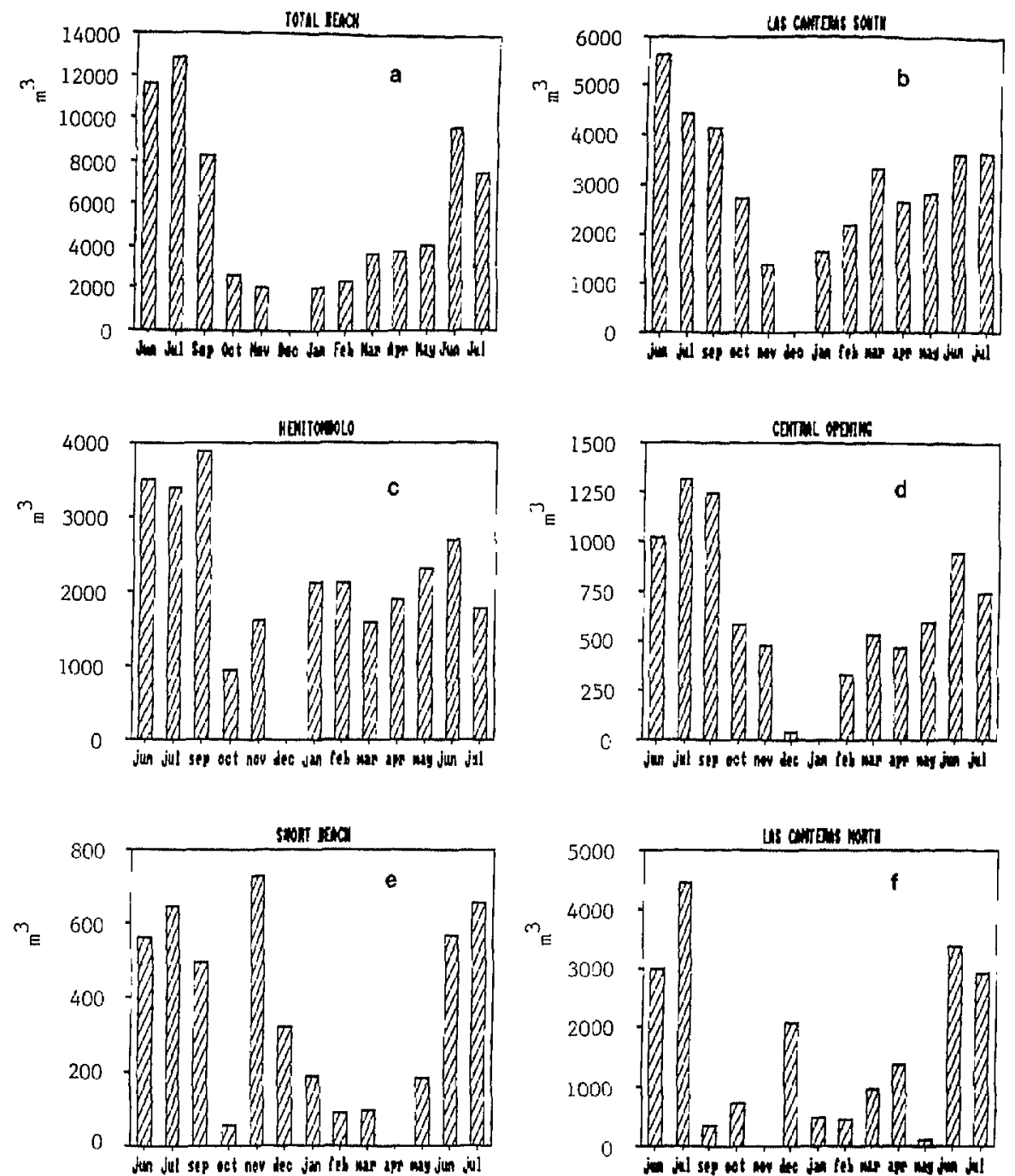

Fig.5. Monthly variations in sediment volume (in $\mathrm{m}^{3}$ ) during the pericd of study: a, whole beach; $b-f$, different sectors (see text).

indie? tes that increases of sand occur in the summer, whereas a decrcase takes place between autumn and spring. This, in fact, fits perfectly in with swell data obtained from seagoing ships. In Fig.6 the data from observations of northern, northeastern and norlhwestern swell have been plotted for the year. These swells are very energetie, since the wave height in deep water is more than $12 \mathrm{ft}$.

During the summer trade winds from the north-northeast are prevailing, but due to the effeet of diffraction, these swells are unable to erode when they arrive at the 


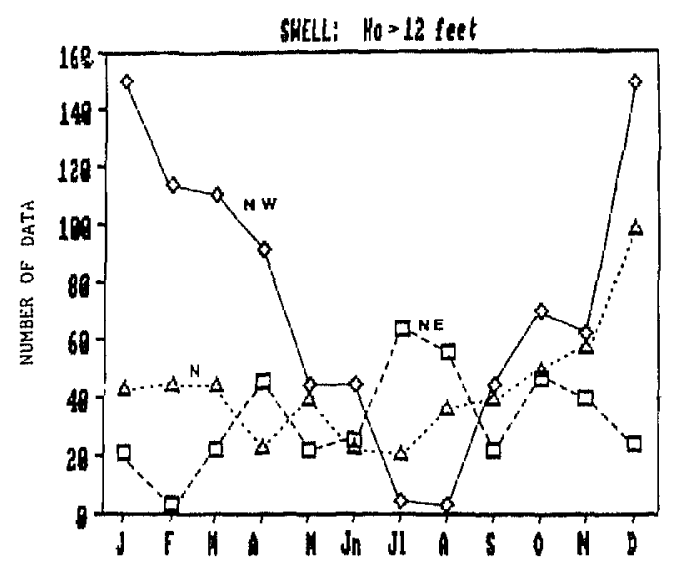

Fig.6. Maritime climate offshore the northern coast of Gran Canaria.

beacl. There is, however, enough energy to settle sand on the foreshore of the submerged beach. Concurrently the greatest accretion takes place during the summer. Between October and April trade winds are weaker but western and northwestern storms appear, affecting the beach directly. The main erosive processes take place under these conditions.

In each sector, the following peculiarities can be observed (Fig.5b,c,d,e,f):

(a) Between profiles 1 and 6 (stretches named Las Canteras South, Hemitombolo and Central opening), the greatest accretion occurs during the summer, whereas the greatest erosion takes place in December.

(b) On the Short Beach the sedimentary behaviour is very umusual since the greatest accretions takes place in the autumn and the main erosion occurs in the spring. This anomalous behaviour is possibly due to the special boundary conditions in this sector.

(c) On the northern end of Las Canteras, significant variations were observed for short periods of time. It can be explained by sediment re-distributions, since this part receives most of the sand eroded from other sectors of the beach.

The processes described can be qualitatively and quantitatively characterised by means of the two indices identified above, which can be of significance for planning. Values of the sediment variability index lower than 0.75 are indicative of slight changes, $0.75-1.5$ of moderately changing beaches and values greater than 1.5 of strongly changing beaches. In the case of sediment support capacity index, beaches with vulues between -0.3 and 0.3 would be in equilibrium: -0.3 to -0.6 and $<-0.6$ would correspond, respectively, to moderately deficient and strongly deficient beaches, whereas 0.3 to 0.6 and $>06$ would indicate beaties wh a mor rase and a strong surplus, respectively.

Table IV shows the values for both incices on each sector of the beach. I be length of cach sector is also indicated. It is necessary to bear in mind that both indices are a function of a surface corresponcing to an intertidal strip $21 \cdot \mathrm{m}$ wide, for each one of the sectors considered. 
TABLEIV

Sedimentary rates on the Las Canteras beach

\begin{tabular}{|c|c|c|c|c|}
\hline \multirow[t]{2}{*}{ Sector } & \multirow{2}{*}{$\begin{array}{l}\text { Studied } \\
\text { length } \\
\text { (m) }\end{array}$} & \multicolumn{2}{|c|}{ Sediment variability index (m) } & \multirow{2}{*}{$\begin{array}{l}\text { Sediment support } \\
\text { capacity index }(\mathrm{m})\end{array}$} \\
\hline & & $\begin{array}{l}\text { from erosion } \\
\text { to accretion }\end{array}$ & $\begin{array}{l}\text { from accretion } \\
\text { to erosion }\end{array}$ & \\
\hline Las Canteras South & 400 & 0.68 & 0.44 & 0.536 \\
\hline Hemitombolo & 450 & 0.41 & 0.29 & 1.053 \\
\hline Central opening & 120 & 0.52 & 0.37 & 0.879 \\
\hline Short Beach & 90 & 0.38 & 0.35 & \\
\hline Las Canteras North & 950 & 0.22 & 0.17 & 0.700 \\
\hline Whole berch & 2010 & 0.29 & 0.23 & 0.727 \\
\hline
\end{tabular}

There are two values for the sediment variability index for each sector. The first one is from the highest erosion to the greatest accretion and the second one is conversely. It must be noted that the months in which erosion and accretion are greatest, are different for each sector of the beach (Fig.5).

This establishes a new correspondence between high values of this index and a predominantly dissipative sector, whereas low values correspond to a reflective beach.

As for the sediment support capacity index, positive values suggest that more sand is found than would be expected, this being in accordance with the findings on the beach. During the last century, when there were no buildings at all, sand from the beach fed a dune field by means of acolian transport. Today, this transport is totally broken by back beach constructions. Thercforc, sand remains on the beach, this being the reason for the positive values.

From the comments above, it appears that the indices obtained can be useful indicators for beach-use planning and management. These indices should be considered for: (a) the preparation of projects for the regulation of the use of beaches and for carrying out works to improve their conditions: (b) in the monitoring and follow-up of interventions on beaches, in order to cetcct unwanted disturbances in sediment behaviour and to introduce the necessary corrective measures.

\section{CONCLUSIONS}

(1) The beach under study is constituted mainly of sand of medium and fine grain size. Carbonates represent $38 \%$ of the total weight.

(2) A corresponje:ice is stablished between an open sedimentary system with a nearly dissrandye beach, and a closed sedimentary system with a reflective beach.

(3) Along the foreshore, accretionary prdcesses occur in the summer, when the northeastern swel s prevailing Erosion takes place between autumn and spring in relation to northwestern storns.

(4) be sedment variability index permits the establishment of a now relationship, 
due to the fact that a reflective beach has low values, whereas a dissipative beach has higher values.

(5) The sediment support capacity index shows that there is an excess of sand on the beach whichis due to the interruption of aeolian sand transport by buildings.

(6) These indices can be useful indicators for planning human interventions on beaches and for monitoring their behaviour.

\section{REFERENCES}

Bascom, IV.N., 1951. The relationship between sand size and beach-face slope. Trans. Am. Geophys. Union, 32: 866-74.

Komar, P.D., 1976. Beach Processes and Sedimentation. Prentice-Hall, Englewood Cliffs, N.J., 429 pp. Martinę, J., 1987. Playas de Gran Canaria (España): Los carbonatos de sus arenas. Bol. Inst. Esp. Oceanogr., 4(2): 87-95.

Martinez, J., Go:do, C., Jimenez, J.A., Santana, J.A. and Veloso, J.J., 1988. Dinámica sedimentaria en la playa de Las Canterus (Las Palmas de Gran Canaria). Rev. Obras Públicas, Feb., pp. 145-152.

Sunamura, T., 1984. Quantitative predictions of beach-iaces slopes. Gcol. Soc. Am. Bull., 95: 242-45.

Wright, L. and Short, A., 1983. Morphodynamics of beaches and sur 5 zones in Australia. In: P.D. Komar (Editor), Handbook of Coastal Processes and Erosion. C.R.C. Press, Boca Raton, Fla., pp.35-64. 